Published in: Plant Biosystems 147 (2013): 343-353

Copy edited version is available in the publisher's homepage:

http://www.tandfonline.com/doi/abs/10.1080/11263504.2012.753485\#.UrmXJ7RUqHY

\title{
Can management intensity be more important than environmental factors? A case study along an extreme elevation gradient from Central Italian cereal fields
}

Robert W. Pal ${ }^{\mathrm{a}}$, Gyula Pinke ${ }^{\mathrm{b}}$, Zoltán Botta-Dukát ${ }^{\mathrm{c}}$, Giandiego Campetella ${ }^{\mathrm{d}}$, Sándor Bartha ${ }^{\mathrm{c}}$, Renátó Kalocsai ${ }^{\mathrm{e}}$, Attila Lengyel ${ }^{\mathrm{f}}$

${ }^{a}$ Institute of Biology, Faculty of Sciences, University of Pécs, Pécs, Hungary ${ }^{b}$ Department of Botany, Faculty of Agricultural and Food Sciences, University of West Hungary, Mosonmagyaróvár, Hungary ${ }^{c}$ Institute of Ecology and Botany, Hungarian Academy of Sciences, Vácrátót, Hungary ${ }^{d}$ School of Environmental Science, Botany and Ecology section, University of Camerino, Italy ${ }^{e}$ Department of Soil Cultivation, University of West Hungary, Mosonmagyaróvár, Hungary ${ }^{f}$ Department of Plant Systematics, Ecology and Theoretical Biology, Eötvös Loránd University, Budapest, Hungary

\begin{abstract}
The paper aims to assess the importance of environmental and management factors determining the weed species composition along a strong elevation gradient. 76 cereal fields (39 low input and 37 intensively-managed) were sampled along an elevation gradient in Central Italy. Explanatory variables were recorded for each field to elucidate the role of largescale spatial trends, site specific, abiotic environmental conditions and field management characters. Redundancy analysis was used to assess the relative importance of each environmental variable in explaining the variation in species composition. Our results indicate that variation in weed species composition is strongly determined by altitude, mean annual precipitation, mean annual temperature and also by different soil characteristics. However, the level of intensification proved to be the most influential variable. There was a significant difference in species richness and composition between low input and intensively managed fields. Intensification leads to considerable species loss at both lower and higher elevations. Low input fields had 296 species in total, while intensively-managed fields had only 196.
\end{abstract}

Keywords: intensification, intensively-managed fields, low input fields, RDA analysis, species richness, weed vegetation

\section{Introduction}

Agricultural intensification can reduce the diversity of arable weed communities (Pinke et al. 2009; Storkey et al. 2012; Brütting et al. 2012), which provide not only conservational and aesthetic value but also a wide variety of ecological services (Altieri 1999; Marshall et al. 2003; Barberi et al. 2010). The increased use of fertilizers and herbicides and a simplified crop-rotational scheme has become more and more common. This process leads to landscape homogenization, resulting in decreased plant diversity and changes in species composition (Burel et al. 1998; Tscharntke et al. 2005; José-María et al. 2010, 2011; KovácsHostyánszki et al. 2010).

Species composition and diversity of arable fields can be influenced by several factors; disentangling the roles they play has been a major focus of weed research. Climatic factors and management practices have been shown to determine the weed species composition both 
in the Czech Republic and Hungary (Lososová \& Cimalová 2009; Pinke et al. 2009, 2010, 2011b, 2012). Kikvidze et al. (2011) found that species richness correlated positively with a composite climate variable, which is the product of maximum temperature and precipitation. Significant changes in weed species composition were associated with a complex gradient of increasing altitude and precipitation and decreasing temperature and base status of the soils in Central Europe (Lososová et al. 2004). Longitude and precipitation were the most important environmental parameters for the weed vegetation of oilseed rape in Germany (Hanzlik \& Gerowitt 2011). Phytogeography, crop type, altitude and sowing season were also important determinants of weed composition in the north-western Balkans (Šilc et al. 2009). Soil properties such as clay content, texture, $\mathrm{pH}$, different nutrients and certain management variables also influenced the occurrence of some weed species (Andreasen \& Streibig 1991; Fried et al. 2008).

Crop production systems in Central Italy are fairly heterogenous. Large, nearly weedfree intensively-managed fields are prevailing, while many low-input agricultural systems can also be found. There is also a large amount of variation in geographical and edaphic characteristics, since arable fields are distributed from the sea level to the high mountain ranges in different soil types (Anselmi 1975; Catorci 2007; Catorci \& Gatti 2010). A significant trend towards intensification and abandonment of small low input fields and pastures in the mountain ranges has been observed in the last 50 years, (Pedrotti 1978; Marini et al. 2011, Rippa et al. 2011) and there is very little ecological knowledge about the consequences of these changes.

The objective of this study was to determine and rank the relative importance of field management regime and certain environmental variables on weed species composition and richness along a strong elevation gradient. To our knowledge, examining the weed species composition in conjunction with assessing the importance of numerous environmental factors has not been done before in Southern Europe. Similar studies have already been carried out in several northern countries (Lososová et al. 2004; Pyšek et al. 2005; Pinke et al. 2009; Šilc et al. 2009), and the present work allows us to assess whether the trends in the studied region are similar to that of more temperate areas.

\section{Materials and Methods}

\section{Study area}

The study area, with size of approximately 223.200 ha, is located in Central Italy, in the southern part of Marche region, between the provinces of Macerata, Fermo and Ascoli Piceno, at about $43^{\circ} 00^{\prime} 11.2^{\prime \prime} \mathrm{N}$ and $13^{\circ} 34^{\prime} 48.6^{\prime} \mathrm{W}$ (Fig. 1a,b). The 76 sampling areas, represented by arable fields (Fig. 1c), range in altitude from $22 \mathrm{~m}$ in the vicinity of the Adriatic coast to $1150 \mathrm{~m}$ in the heart of Apennines (Fig. 1d). Consequently, the climatic conditions are strongly heterogeneous, varying in mean annual temperature from 8 to $17 \mathrm{C}^{\circ}$ and from 600 to $1300 \mathrm{~mm}$ in mean annual precipitation. Two macroclimatic regions can be distinguished within the investigated area: a) Mediterranean, located in the southern part of Monte Conero, only in the eastern sector near the coast, and b) Temperate, in the rest of the region, with a transitional belt in the hilly landscape included between 400 and 600m (Biondi \& Baldoni 1991).

\section{Survey method}


Vegetation data from arable fields were recorded during May/June of 2008. The gradient is included in a grid system of 20 UTM geographical quadrats $(10 \times 10 \mathrm{~km})$. In each quadrat, four arable fields were chosen (two low input and two intensively-managed fields); in four quadrats where a large portion of the area was occupied by the sea or high mountains, only two fields were selected. Thus we sampled plots from 39 low input and 37 intensivelymanaged fields. According to Hofmeister (1992), the main features of low input cropping are: high cereal proportion in the crop rotation, on-farm production of crop seed, low sowing density, shallow tillage, limited fertiliser application and no pesticide usage, late stubble ploughing and only occasional application of mechanical weed control. Based on our field observations. such fields were usually smaller in size (1-2 ha or smaller), and there were no signs of herbicide application. Larger fields $(<2$ ha) with perceived herbicide applications (traces of spraying machinery and weed injuries were detected) represented intensive farming system (Table 1).

Weed vegetation of the fields was assessed in 10 randomly selected $1 \mathrm{~m}^{2}$ plots located in the field edges inside the outermost seed drill line. In this way 760 one-square-meter plots were sampled in total in which vascular plants were identified to species level, and their frequencies were calculated for each field. Taxonomic nomenclature follows Tutin et al. (1968-1980, 1993).

Explanatory variables were recorded for each field, reflecting: 1) large-scale spatial trends (altitude, mean annual precipitation, mean annual temperature); 2) site specific, abiotic environmental conditions (soil texture, $\mathrm{pH}_{\mathrm{KCl}}$, humus, $\mathrm{CaCO}_{3}, \mathrm{~K}_{2} \mathrm{O}, \mathrm{P}_{2} \mathrm{O}_{5}$ ); and 3) field management characteristics (management regime, i.e. low input or intensively-managed field). The climatic data of each field follows Amici \& Spina (2002) and Spina et al. (2007). Soil samples were collected at a depth of $0-15 \mathrm{~cm}$, and physical and chemical analyses were performed on the 0-2mm air dried soil fraction. Texture, $\mathrm{pH} \mathrm{KCl}$, humus, $\mathrm{P}_{2} \mathrm{O}_{5}, \mathrm{~K}_{2} \mathrm{O}$ and $\mathrm{CaCO}_{3}$ were determined in a laboratory accredited by DAP (German Accreditation System for Testing).

The study fields were cropped by the following winter cereals: wheat (Triticum aestivum L., Triticum durum Desf.), barley (Hordeum vulgare L., Hordeum distichon L.), triticale $(\times$ Triticosecale rimpaui $\mathrm{Wittm}$.) and rye (Secale cereale $\mathrm{L}$.$) .$

\section{Data analysis}

In total, 76 plots were obtained and they were entered into a TURBOVEG database (Hennekens \& Schaminée 2001). Predictor variables were related to species compositional data by redundancy analysis (RDA, Podani 1994). Before the RDA, species data were transformed by Hellinger's formula which makes them suitable for direct ordination if responses are unimodal (Legendre \& Gallagher 2001). Explanatory power of the full model (comprising all predictor variables) was expressed by the proportion of explained and total variance, and its significance was assessed by a permutation test. The set of predictor variables was also evaluated by testing each predictor separately, according to the methodology of Lososová et al. (2004). Due to collinearities among variables, the total amount of variance explained by a single predictor includes a proportion that is also related to other predictors, while the remaining proportion is independent from other predictors and can be attributed only to the single one we examine. Thus, explanatory power of each predictor can be expressed by its gross effect that includes variance shared with other predictors, and its subset, the net effect, that is the variance explained only by the considered predictor. The gross effect of each predictor was obtained from a redundancy analysis using that single explanatory variable. Net effects were calculated similarly but with the inclusion of all the other background factors as covariables. In order to characterize intensively-managed and low input management types with species composition, plots were grouped according to 
management, and fidelity values of species were calculated for these two clusters. The phi coefficient was used as the measure of fidelity (Chytrý et al. 2002) with adjustment for equal group sizes (Tichý \& Chytrý 2006). All statistical analyses were performed in R software environment ( $\mathrm{R}$ Development Core Team 2010) using the vegan package (Oksanen et al. 2010).

\section{Results}

Overall 296 weed species were recorded in the dataset of which 241 were forbs, 45 grasses, 5 trees, 3 shrubs and 2 rushes. The species richness differed considerably between the two management types. Low input fields had 296 species in total, while intensively-managed fields had only 196. There were significant differences between the species number within the two management types at the level of the fields and the plots as well (Fig. 2). There was a significant trend towards higher species richness with increasing elevation within both management types (Fig. 3). According to fidelity measures (based on phi-coefficient), low input fields have 9 characteristic species, while intensively-managed fields have none (Table 2).

The RDA model explained $28.23 \%$ of the total variation (Table 3). Weed species composition was strongly related to several factors; among these the management regime was the most significant, with both gross and net effects equally high $(\mathrm{p}<0.005)$. Large scale spatial trends (altitude, mean annual temperature, mean annual precipitation) were highly important variables, all their gross effects were significant $(\mathrm{p}<0.005)$; however, the net effect was highest for altitude. Numerous site specific, abiotic environmental conditions such as certain soil characteristics, also explained a large part of the total variation.

Several environmental factors showed significant correlation with altitude (Fig. 4). Mean annual temperature $(\mathrm{r}=-0.749)$, mean annual precipitation $(\mathrm{r}=0.741)$ and soil texture $(\mathrm{r}=0.467)$ were highly significant $(\mathrm{p}<0.001)$, while $\mathrm{CaCO}_{3}(\mathrm{r}=-0.02885), \mathrm{K}_{2} \mathrm{O}(\mathrm{r}=-0.03151)$ and $\mathrm{P}_{2} \mathrm{O}_{5}(\mathrm{r}=-0.2617)$ content of the soil did not show a strong correlation with changing altitude. The relationship between the environmental variables and the weed species with the highest fit are listed in Table 4.

In the RDA ordination diagram (Fig. 5), the first axis corresponded to altitude, mean annual precipitation, mean annual temperature and different soil characteristics (soil texture, humus, $\left.\mathrm{CaCO}_{3}, \mathrm{P}_{2} \mathrm{O}_{5}, \mathrm{pH}\right)$. The second axis correlated with management regime and $\mathrm{K}_{2} \mathrm{O}$ content of the soil.

The first two axes of the RDA ordination show that most weeds preferred low input fields. There were species (Fig. 6) (Anthemis arvensis, Bromus sterilis, Consolida regalis, Myosotis arvensis, Ranunculus arvensis, Viola arvensis) that preferred higher altitude, higher amount of mean annual precipitation, lower mean annual temperature, higher humus content and heavier soils. In contrast, fields at lower altitudes, with higher mean annual temperature, lower mean annual precipitation, looser soils and lower humus content, could be characterized by the following weed species: Anagallis arvensis, Avena fatua, Chamomilla recutita, Cynodon dactylon, Lolium multiflorum, Picris echioides, Polygonum aviculare.

\section{Discussion}

\section{Species richness of the investigated fields}

Management regime of the studied arable fields proved to be one of the most important factors determining species richness in our study. Low input fields had significantly more species than intensively-managed ones. José-María et al. (2010) also verified that agricultural intensification affects plant assemblages in arable fields. Several studies have 
indicated higher diversity and weed biomass from low input arable fields across Europe (Glemnitz et al. 2006; Hyvönen \& Salonen 2005; Pinke et al. 2009).

In our study, eight species can be named as characteristic elements of low input fields, and there are 15 weeds that are most strongly associated with this management type. Many of these species (e.g. Galium tricornutum, Legousia hybrida, Legousia speculum-veneris, Scandix pecten-veneris, Sherardia arvensis) are listed as threatened or even extinct weed species in Central Europe (Pinke et al. 2011a). It is also important to emphasize that weed species are more sensitive and less vigorous under intensified agriculture at the limit of their range in western and northern Europe (Holzner 1978). Our research indicated that those weed species threatened in Central Europe can be much more frequent in the southern European study area, which can be regarded as their original (core) area.

Our results demonstrated that species number in arable fields in Central Italy significantly increased with increasing elevation, similarly to the findings from Central Europe (Lososová et al. 2004). Interestingly however, Pyšek (1993) confirmed that species number is negatively correlated with elevation in urban areas. According to Siniscalco et al. (2011) the number of non-native plant species decreased strongly with increasing elevation. Suzart de Albuquerque et al. (2010) found that plant species richness can be well predicted by water availability. In our study area, mean annual precipitation was correlated with elevation, thus higher species richness can also be related to higher amount of available water.

\section{Species composition of the investigated fields}

The present research was carried out along a relatively strong elevation gradient, resulting in a wide range of climatic conditions within the study area. Therefore, altitude, mean annual temperature and mean annual precipitation were important factors determining species composition, although their net effects were moderate. However, these factors are strongly correlated and, in the case of net effect analysis, including two of them as covariables could mask the individual importance of the third. This connection is also interpreted in the research of Hügin (1999). Therefore there are weed species which correspond to higher altitude and a higher amount of mean annual precipitation, but negatively associated to temperature. Such species are: Viola arvensis, Consolida regalis, Bromus sterilis, Eranthis hyemalis. At the same time, there are such species which are associated with lower altitudes, lower amount of mean annual precipitation and a higher mean annual temperature; e.g. Chamomilla recutita, Lolium multiflorum, Cynodon dactylon, Polygonum aviculare, Bromus madritensis, Chenopodium album, Conyza canadensis, Picris echioides and Desmazeria rigida showed a strong correlation with lower mean annual precipitation and higher mean annual temperature, but we found no significant preference in altitude.

Soil texture was also a highly important variable. Soils in higher elevation were generally more compacted. Alopecurus bulbosus, Eranthis hyemalis, Centaurea cyanus, Neslia paniculata and Bunium bulbocastanum are some species that prefer more compacted soils. In contrast, Chamomilla recutita, Lolium multiflorum, Polygonum aviculare, Capsella bursa-pastoris and Bromus madritensis were associated with less compacted soils. Fried et al. (2008) found soil texture as a significant factor in determining species composition in France. For segetal weeds, soil $\mathrm{pH}$ is one of the most important factors explaining species assemblages (Fried et al. 2008; Climanová \& Lososová 2009; Pinke et al. 2010). Our results indicate that soil $\mathrm{pH}$ was not a highly significant factor in the studied area. Although its gross effect was significant, the net effect did not confirm this. This is probably due to the low $\mathrm{pH}$ range $\left(\mathrm{pH}_{\mathrm{KCl}} 7.06-7.58\right)$ of the investigated area. There were nonetheless a few species that were associated with lower or higher $\mathrm{pH}$ values (Table 3 ). Humus content of the soil was also an important soil property that defined species composition. The species associated most with higher humus content were Viola arvensis, Centaurea cyanus, Medicago lupulina and Bunium 
bulbocastanum. Bretzel et al. (2009) found that Chamomilla recutita as native weed in the Mediterranean prefers phosphorus rich soils for its emergence and for a larger biomass. This is consistent with our results, as this weed was associated with high $\mathrm{P}_{2} \mathrm{O}_{5}$ content. Tarmi et al. (2009) found that species diversity negatively related with the amount of phosphorus. Our results did not confirm this, but the trend was similar. $\mathrm{CaCO}_{3}$ content of the soil positively affected the occurrence of the following species: Alopecurus myosuroides, Ranunculus arvensis, Veronica hederifolia, Consolida regalis, Symphytum tuberosum, but was negatively associated with the presence of Lolium multiflorum, Capsella bursa-pastoris, Clematis vitalba, Poa pratensis and Arabidopsis thaliana. Among these, Ranunculus arvensis and Consolida regalis are classified as Caucalion species that are basiphilous weeds and most of their members are threatened in northern Europe (Pinke 2004).

Our results indicate that many environmental factors along the investigated gradient are associated with the variation in weed species composition. However, the level of intensification, independent of other environmental factors, was the most influential both in higher and lower elevations. In our study, management regime was the only factor where gross and net effects were equally high. Several studies have supported the findings that management regime is one of the most important variable influencing the species composition of weed vegetation (Fried et al. 2008; Pinke et al. 2009), but our work emphasizes its importance even when accounting for other environmental factors.

\section{Conclusions}

Intensive management regime was the strongest factor influencing weed communities along the investigated gradient. It eliminates those species that are indicators of other factors. Large scale environmental variables and site-specific conditions also impacted species assemblages significantly. Our findings support the view that agricultural intensification negatively affects species diversity and has a large effect on species composition in southern Europe as well.

Low input cereal fields in higher elevation were the most species-rich, however, these fields are most likely to be abandoned in the future as they are usually owned by older farmers, and after the decline of this traditional peasant culture, there will be no younger generation continuing this kind of lifestyle. On the other hand, low input fields are also largely intensified, but in the mountain range this is not very profitable. Degradation of traditional landscape in Central Italy is not just a local problem as it was stated in the research of Agnoletti (2007) and Rippa (2011). As a consequence, more and more arable weeds will become threatened, and species diversity of the cereal fields could dramatically decrease in Southern Europe, similarly to which was already described from Central Europe (Pinke et al. 2009).

Low intensity arable farming systems of a high ecological quality are rare and confined to southern and eastern Europe (Stoate et al. 2009). It is important to emphasize that such low input arable habitats merit a high priority for biodiversity conservation. Kleijn et al. (2009) also suggested that conservation initiatives are most effective if they are preferentially implemented in extensively farmed areas that still support high levels of biodiversity. The study of Armengot et al. (2011) revealed that landscape complexity had a limited role in affecting weed flora of inner fields. Accordingly, strategies for weed flora conservation within arable fields in a Mediterranean context should focus on promoting low-intensity agricultural practices rather than on the surrounding landscape.

\section{Acknowledgements}

This work was supported by the Erasmus Teaching Staff Mobility between the University of Pécs (Hungary) and the University of Camerino (Italy) and the Carpathes Nature 
Conservation Foundation. We are grateful to the Italian farmers for the permission to access their land. Thanks to Domenico Lucarini (University of Camerino) for his help in solving taxonomical difficulties to Emily Rauschert (The Pennsylvania State University) for useful comments and linguistic improvement of the text.

\section{References}

Agnoletti M. 2007. The degradation of traditional landscape in a mountain area of Tuscany during the 19th and 20th centuries: Implications for biodiversity and sustainable management. Forest Ecol Manag 249: 5-17.

Altieri MA. 1999. The ecological role of biodiversity in agroecosystems. Agr Ecosyst Environ 74: 19-31.

Amici M., Spina R., 2002. Campo medio della precipitazione annuale e stagionale sulle Marche per il periodo 1950-2000. Regione Marche, Centro di Ecologia e Climatologia, Osservatorio Geofisico Sperimentale, Macerata, pp. 126.

Anselmi S. 1975. La selva, il pascolo, l'allevamento nelle Marche dei secoli XIV e XV. Università di Urbino, Istituto di economia e statistica. Urbino, Aralia Editore.

Andreasen C, Streibig JC. 1991. Soil properties affecting the distribution of 37 weed species in Danish fields. Weed Res 31: 181-187.

Armengot L, Jose-Maria L, Blanco-Moreno JM , Romero-Puente A, Sans FX. 2011. Landscape and land-use effects on weed flora in Mediterranean cereal fields. Agr Ecosyst Environ 142: 311-317.

Barberi P, Burgio G, Dinelli G, Moonen AC, Otto S, Vazzana C, et al. 2010. Functional biodiversity in the agricultural landscape: Relationships between weeds and arthropod fauna. Weed Res 50: 388-401.

Biondi E, Baldoni M. 1995. A possible method for geographic delimitation of phytoclimatic types: with application to the phytoclimate of the Marche region of Italy. Doc Phytosociol 15: 15-28.

Bretzel F, Pezzarossa B, Benvenuti S, Bravi A, Malorgio F. 2009. Soil influence on the performance of 26 native herbaceous plants suitable for sustainable Mediterranean landscaping. Acta Oecol 35: 657-663.

Brütting C, Wesche K, Meyer S, Hensen I. 2012. Genetic diversity of six arable plants in relation to their Red List status. Biodivers Conserv 21: 745-761.

Burel F, Baudry J, Butet A, Clergeau P, Delettre Y, Le Coeur D, Dubs F, Morvan L, Paillat G, Petit S, Thenail C, Brunel E, Lefeuvre J-C. 1998. Comparative biodiversity along a gradient of agricultural landscapes. Acta Oecol 19: 47-60.

Catorci A. 2007. Lineamenti storico economici del paesaggio pastorale maceratese. BraunBlanquetia 42: 39-45.

Catorci A, Gatti R. 2010. Floristic composition and spatial distribution assessment of montane mesophilous grasslands in the central Apennines, Italy: A multi-scale and diachronic approach. Plant Biosyst 144: 793-804.

Chytrý M, Tichý L, Holt J, Botta-Dukát Z. 2002. Determination of diagnostic species with statistical fidelity measures. J Veg Sci 13: 79-90.

Cimalová Š, Lososová Z. 2009. Arable weed vegetation of the northeastern part of the Czech Republic: effects of environmental factors on species composition. Plant Ecol 203: 4557.

Fried G, Norton LR, Reboud X. 2008. Environmental and management factors determining weed species composition and diversity in France. Agr Ecosyst Environ 128: 68-76.

Glemnitz M, Radics L, Hoffmann J, Czimber G. 2006. Weed species richness and species composition of different arable field types - A comparative analysis along a climate gradient from south to north Europe. J Plant Dis Protec 20: 577-586. 
Hanzlik K, Gerowitt B. 2011: The importance of climate, site and management on weed vegetation in oilseed rape in Germany. Agr Ecosyst Environ 141: 323-331.

Hennekens SM, Schaminée JHJ. 2001. TURBOVEG, a comprehensive database management system for vegetation data. J Veg Sci 12: 589-591.

Hofmeister H. 1992. Ackerwildkrautschutz auf der Wernershöhe (Landkreis Hildesheim, Nordwest-Deutschland). Tuexenia 12: 285-298.

Holzner W. 1978. Weed species and weed communities. Vegetatio 38, 13-20.

Hügin G. 1999. Was sind Wärmezeiger? Untersuchungen zum Wärmebedürfnis von Ruderalund Segetalpflanzen in Mitteleuropa. Tuexenia 19: 425-445.

Hyvönen T., Salonen J. 2005. Biomass production of weeds in low input and conventional cropping of cereals. Biol Agric Hortic 23: 181-173.

José-María L, Armengot L, Blanco-Moreno JM, Bassa M, Sans FX. 2010. Effects of agricultural intensification on plant diversity in Mediterranean dryland cereal fields. $\mathbf{J}$ Appl Ecol 47: 832-840.

José-María L, Blanco-Moreno JM, Armengot L, Sans FX. 2011. How does agricultural intensification modulate changes in plant community composition? Agr Ecosyst Environ 145: 77-84.

Kikvidze Z, Michalet R, Brooker RW, Cavieres LA, Lortie CJ, Pugnaire FI, Callaway RM. 2011. Climatic drivers of plant-plant interactions and diversity in alpine communities. Alp Botany 121: 63-70.

Kleijn D, Kohler F, Báldi A, Batáry P, Concepcio'n ED, Clough Y, et al. 2009. On the relationship between farmland biodiversity and land-use intensity in Europe. Proc Roy Soc Lond B Biol Sci 276: 903-909.

Kovács-Hostyánszki A, Batáry P, Báldi A, Harnos A. 2011. Interaction of local and landscape features in the conservation of Hungarian arable weed diversity. Appl Veg Sci 14: 4048.

Legendre P, Gallagher EG. 2001. Ecologically meaningful transformations for ordination of species data. Oecologia, 129: 271-280.

Lososová Z, Chytrý M, Cimalová Š, Kropáč Z, Otýpková Z, Pyšek P, Tichý L. 2004. Weed vegetation of arable land in Central Europe: Gradients of diversity and species composition. J Veg Sci 15: 415-422.

Lososová Z, Cimalová S. 2009. Effects of different cultivation types on native and alien weed species richness and diversity in Moravia (Czech Republic). Basic Appl Ecol 10: 456465.

Marini L, Klimek S, Battisti A. 2011. Mitigating the impacts of the decline of traditional farming on mountain landscapes and biodiversity: a case study in the European Alps. Environ Sci Policy 14: 258-267.

Marshall EJP, Brown VK, Boatman ND, Lutman PJW, Squire GR, Ward LK. 2003. The role of weeds in supporting biological diversity within crop fields. Weed Res 43: 77-89.

Oksanen J, Blanchet FG, Kindt R et al. 2010. Vegan: Community Ecology Package. R package version 1.17-2. Available at: http://CRAN.R-project.org/package=vegan

Pedrotti F. 1978. Einige Bemerkungen über die Entwicklung der Vegetation im Naturreservat von Torricchio. Phytocoenosis 7: 11-19.

Pinke G. 2004. Letzte Vorkommen von Caucalion-Arten im Nordwestern Ungarns. Z Pflanzenk Pflanzen 19: 73-82.

Pinke G, Pál R, Botta-Dukát Z, Chytrý M. 2009. Weed vegetation and its conservation value in three management systems of Hungarian winter cereals on base-rich soils. Weed Res 49: 544-551.

Pinke G, Pál R, Botta-Dukát Z. 2010. Effects of environmental factors on weed species composition of cereal and stubble fields in western Hungary. Cent Eur J Biol 5: 283292. 
Pinke G, Király G, Barina Z, Mesterházy A, Balogh L, Csiky J, Schmotzer A, Molnár VA, Pál RW. 2011a. Assessment of endangered synanthropic plants of Hungary with special attention to arable weeds. Plant Biosyst 145: 426-435.

Pinke G, Pál R, Tóth K, Karácsony P, Czúcz B, Botta-Dukát Z. 2011b. Weed vegetation of poppy (Papaver somniferum) fields in Hungary: Effects of management and environmental factors on species composition. Weed Res 51: 621-630.

Pinke G, Karácsony P, Czúcz B, Botta-Dukát Z, Lengyel A. 2012: The influence of environment, management and site context on species composition of summer arable weed vegetation in Hungary. Appl Veg Sci 15: 136-144.

Podani J. 1994. Multivariate Data Analysis in Ecology and Systematics. SPB Publishing, The Hague. pp. 316.

Pyšek P. 1993. Factors affecting the diversity of flora and vegetation in central European settlements. Vegeiatio 106: 89-100.

Pyšek P, Jarošik V, Kropáč Z, Chytrý M, Wild J, Tichý L. 2005. Effects of abiotic factors on species richness and cover in Central European weed communities. Agr Ecosyst Environ 109: 1-8.

R Development Core Team 2010. R: A language and environment for statistical computing. R Foundation for Statistical Computing, Vienna, Austria. ISBN 3-900051-07-0, URL http://www.R-project.org.

Rippa D, Maselli V, Soppelsa O, Fulgione D. 2011. The impact of agro-pastoral abandonment on the Rock Partridge Alectoris graeca in the Apennines. Ibis 153: 721-734.

Šilc U, Vrbničanin S, Božić D, Čarni A, Dajić Stevanović Z. 2009. Weed vegetation in the northwestern Balkans: diversity and species composition. Weed Res 49: 602-612.

Siniscalco C, Barni E, Bacaro G. 2011. Non-native species distribution along the elevation gradient in the western Italian Alps. Plant Biosyst 145: 150-158.

Spina R., Stortini S., Fusari R., Scuterini C., Di Marino M. 2007. Caratterizzazione climatologica delle Marche: campo medio della temperatura per il periodo 1950-2000. Regione Marche, Centro di Ecologia e Climatologia, Osservatorio Geofisico Sperimentale, Macerata, pp. 56.

Stoate C, Báldi A, Beja P, Boatman ND, Herzon I, van Doorn A, et al. 2009. Ecological impacts of early 21 st century agricultural change in Europe - A review. J Environ Manage 91: 22-46.

Storkey J, Meyer S, Leuschner C, Still, KS. 2012. The impact of agricultural intensification and land use change on the European arable flora. Proc R Soc B 279: 1421-1429.

Suzart de Albuquerque F, Castro-Díez P, Rodríguez MÁ, Cayuela L. 2010. Assessing the influence of environmental and human factors on native and exotic species richness. Acta Oecol 30: 1-7.

Tarmi S, Helenius J, Hyvönen T. 2009. Importance of edaphic, spatial and management factors for plant communities of field boundaries. Agr Ecosyst Environ 131: 201-206.

Tichý L, Chytrý M. 2006. Statistical determination of diagnostic species for site groups of unequal size. J Veg Sci 17: 809-818.

Tscharntke T, Klein AM, Kruess A, Steffan-Dewenter I, Thies C. 2005. Landscape perspectives on agricultural intensification and biodiversity - ecosystem service management. Ecol Lett 8: 857-874.

Tutin TG, et al. (eds.) 1968-1980. Flora Europaea, Vol. 2-5. Cambridge University Press, Cambridge.

Tutin TG, et al. (eds.) 1993. Flora Europaea, Vol. 1. (2 ${ }^{\text {nd }}$ Edition). Cambridge University Press, Cambridge. 


\section{LEGENDS (Tables)}

Table 1 Characterization of the differently managed fields (76 fields evenly distributed 39 low input and 37 intensively managed farm). Averages of the factors, ranges in parenthesis. P-value was calculated by Mann-Whitney test

\begin{tabular}{lccc} 
& Low input & Intensive & $\mathrm{p}$ \\
\hline Field size (ha) & $1.3(0.2-5)$ & $2(0.3-5)$ & 0.001 \\
Crop cover $(\%)$ & $33.4(5-90)$ & $50(15-90)$ & 0.001 \\
Weed cover $(\%)$ & $32(6-100)$ & $7.3(1-40)$ & 0.001 \\
Number of weeds (total) & 296 & 196 & - \\
Number of weeds (per field) & $18.6(7-36)$ & $8.9(2-20)$ & 0.001 \\
Preceding crop annual & $39 / 5$ & $37 / 15$ & - \\
$\mathrm{Herbicide} \mathrm{use}$ & no & yes & - \\
pH KCl & $7.27(7.06-7.54)$ & $7.32(7.12-7.54)$ & $\mathrm{n} . \mathrm{s}$ \\
Soil humus content & $2.35(0.84-8.22)$ & $2.09(1.01-5.82)$ & $\mathrm{n} . \mathrm{s}$ \\
Soil $\mathrm{CaCO}$ content & $29.35(5.7-64.9)$ & $33.25(2.7-65.4)$ & $\mathrm{n} . \mathrm{s}$ \\
Soil $\mathrm{K}_{2} \mathrm{O}$ content & $276.66(64.4-645)$ & $279.04(48.2-811)$ & $\mathrm{n} . \mathrm{s}$ \\
Soil $\mathrm{P}_{2} \mathrm{O}_{5}$ content & $68.95(12.5-271)$ & $73.12(10.7-317)$ & $\mathrm{n} . \mathrm{s}$ \\
Soil texture & medium sand-clay & medium sand-clay & - \\
\hline
\end{tabular}

Table 2 Characteristic species with the highest fidelity values (based on phi-coefficient)

\begin{tabular}{lcc}
\cline { 2 - 3 } & Low input & Intensive \\
\hline Vicia sativa & 0.6077005 & --- \\
Legousia speculum- & & \\
veneris & 0.6061515 & --- \\
Arenaria serpyllifolia & 0.5935589 & --- \\
Myosotis arvensis & 0.5591980 & --- \\
Cerastium glomeratum & 0.5210985 & --- \\
Lactuca serriola & 0.5058994 & --- \\
Veronica arvensis & 0.4213387 & --- \\
Scandix pecten-veneris & 0.4208331 & --- \\
Anthemis tinctoria & 0.3909115 & --- \\
\hline
\end{tabular}


Table 3 Effects of explanatory variables on weed species composition, identified using the Monte Carlo tests in redundancy analysis (RDA)

\begin{tabular}{lcccccc} 
& Gross effect & \multicolumn{5}{c}{ Net effect } \\
\cline { 2 - 7 } Variable & var & $\mathrm{F}$ & $\mathrm{P}$ & $\mathrm{var}$ & $\mathrm{F}$ & $\mathrm{P}$ \\
\hline $\begin{array}{l}\text { Altitude } \\
\text { Mean annual }\end{array}$ & 0.048 & 6.525 & 0.005 & 0.014 & 2.113 & 0.005 \\
temperature & & & & & & \\
Mean annual & 0.046 & 6.251 & 0.005 & 0.007 & 1.048 & 0.350 \\
precipitation & & & & & & \\
Soil texture & 0.045 & 6.061 & 0.005 & 0.007 & 1.059 & 0.420 \\
pH KCl & 0.020 & 2.598 & 0.005 & 0.011 & 1.619 & 0.005 \\
Soil humus content & 0.016 & 2.087 & 0.005 & 0.009 & 1.312 & 0.036 \\
Soil CaCO $\mathrm{CO}_{3}$ content & 0.026 & 3.423 & 0.005 & 0.014 & 2.212 & 0.005 \\
Soil $\mathrm{K}_{2} \mathrm{O}$ content & 0.010 & 1.299 & 0.120 & 0.009 & 1.324 & 0.038 \\
Soil $\mathrm{P}_{2} \mathrm{O}_{5}$ content & 0.013 & 1.654 & 0.005 & 0.010 & 1.605 & 0.015 \\
Management regime & 0.019 & 2.411 & 0.005 & 0.008 & 1.293 & 0.050 \\
\hline
\end{tabular}


Table 4 Fit and score values of the 20 species with the highest fit along the first axis in the partial RDA models of the significant explaining variables

\begin{tabular}{lcclrc}
\hline $\begin{array}{l}\text { Management regime } \\
\text { (+ intensive; - extensive) }\end{array}$ & Axis 1 score & Fit & $\begin{array}{l}\text { Altitude } \\
\text { (+ high; - low) }\end{array}$ & Axis 1 score & Fit \\
\hline Convolvulus arvensis & 0.153 & 0.182 & Viola arvensis & 0.155 & 0.326 \\
Elymus repens & 0.150 & 0.132 & Consolida regalis & 0.134 & 0.303 \\
Polygonum aviculare & 0.111 & 0.145 & Bromus sterilis & 0.134 & 0.177 \\
Anagallis arvensis & 0.097 & 0.128 & Centaurea cyanus & 0.081 & 0.241 \\
Veronica persica & 0.095 & 0.156 & Eranthis hyemalis & 0.056 & 0.170 \\
Crepis sancta & -0.026 & 0.095 & Lamium amplexicaule & 0.052 & 0.256 \\
Trifolium campestre & -0.041 & 0.115 & Alyssum alyssoides & 0.050 & 0.251 \\
Sherardia arvensis & -0.059 & 0.108 & Lathyrus sphaericus & 0.049 & 0.316 \\
Galium tricornutum & -0.072 & 0.093 & Vicia tenuifolia & 0.040 & 0.178 \\
Lactuca serriola & -0.072 & 0.213 & Veronica polita & 0.037 & 0.253 \\
Cerastium glomeratum & -0.077 & 0.167 & Conyza canadensis & -0.064 & 0.184 \\
Aphanes arvensis & -0.078 & 0.123 & Papaver hybridum & -0.065 & 0.198 \\
Anthemis tinctoria & -0.079 & 0.142 & Sonchus oleraceus & -0.074 & 0.169 \\
Legousia hybrida & -0.092 & 0.124 & Chenopodium album & -0.088 & 0.186 \\
Scandix pecten-veneris & -0.100 & 0.161 & Bromus madritensis & -0.098 & 0.172 \\
Arenaria serpyllifolia & -0.115 & 0.267 & Anagallis arvensis & -0.120 & 0.195 \\
Myosotis arvensis & -0.115 & 0.254 & Polygonum aviculare & -0.121 & 0.171 \\
Papaver rhoeas & -0.177 & 0.321 & Cynodon dactylon & -0.132 & 0.261 \\
Legousia speculum-veneris & -0.180 & 0.333 & Lolium multiflorum & -0.164 & 0.196 \\
Vicia sativa & -0.180 & 0.361 & Matricaria chamomilla & -0.178 & 0.259 \\
\hline
\end{tabular}

\begin{tabular}{lcclrc}
\hline $\begin{array}{l}\text { Mean annual precipitation } \\
\text { (+ high; - low) }\end{array}$ & Axis 1 score & Fit & $\begin{array}{l}\text { Mean annual temperature } \\
\text { (+ high; - low) }\end{array}$ & Axis 1 score & Fit \\
\hline Bromus sterilis & 0.168 & 0.280 & Lolium multiflorum & 0.181 & 0.240 \\
Consolida regalis & 0.145 & 0.355 & Matricaria chamomilla & 0.173 & 0.246 \\
Viola arvensis & 0.142 & 0.273 & Helminthia echioides & 0.143 & 0.191 \\
Mentha longifolia & 0.133 & 0.201 & Bromus madritensis & 0.119 & 0.251 \\
Silene vulgaris & 0.083 & 0.197 & Catapodium rigidum & 0.117 & 0.185 \\
Potentilla reptans & 0.081 & 0.174 & Polygonum aviculare & 0.113 & 0.151 \\
Centaurea cyanus & 0.068 & 0.170 & Cynodon dactylon & 0.112 & 0.189 \\
Eranthis hyemalis & 0.065 & 0.227 & Chenopodium album & 0.082 & 0.162 \\
Bunium bulbocastanum & 0.051 & 0.171 & Conyza canadensis & 0.074 & 0.243 \\
Adonis flammea & 0.043 & 0.161 & Papaver hybridum & 0.066 & 0.204 \\
Dasypyrum villosum & 0.041 & 0.174 & Calendula arvensis & 0.045 & 0.149 \\
Conyza canadensis & -0.062 & 0.169 & Adonis flammea & -0.042 & 0.154 \\
Chenopodium album & -0.083 & 0.167 & Odontites rubra & -0.054 & 0.153 \\
Bromus madritensis & -0.108 & 0.207 & Eranthis hyemalis & -0.055 & 0.159 \\
Cynodon dactylon & -0.111 & 0.183 & Taraxacum officinale & -0.071 & 0.165 \\
Polygonum aviculare & -0.119 & 0.167 & Knautia integrifolia & -0.075 & 0.165 \\
Catapodium rigidum & -0.124 & 0.207 & Viola arvensis & -0.133 & 0.240 \\
Helminthia echioides & -0.136 & 0.173 & Mentha longifolia & -0.136 & 0.208 \\
Matricaria chamomilla & -0.141 & 0.163 & Consolida regalis & -0.148 & 0.368 \\
Lolium multiflorum & -0.163 & 0.195 & Bromus sterilis & -0.162 & 0.260 \\
\hline
\end{tabular}

Soil humus content

Soil $\mathrm{K}_{2} \mathrm{O}$ content

(+ high; - low)

Axis 1 score $\quad$ Fit

(+ high; - low)

Axis 1 score $\quad$ Fit 


\begin{tabular}{llllll} 
Viola arvensis & 0.095 & 0.123 & Phalaris canariensis & 0.099 & 0.229 \\
Centaurea cyanus & 0.090 & 0.298 & Avena fatua & 0.084 & 0.059 \\
Medicago lupulina & 0.085 & 0.155 & Galium tricornutum & 0.066 & 0.077 \\
Bunium bulbocastanum & 0.085 & 0.477 & Centaurea cyanus & 0.037 & 0.049 \\
Potentilla reptans & 0.067 & 0.117 & Neslia paniculata & 0.035 & 0.087 \\
Adonis flammea & 0.062 & 0.330 & Bunium bulbocastanum & 0.032 & 0.065 \\
Lamium amplexicaule & 0.061 & 0.352 & Sanguisorba minor & 0.031 & 0.086 \\
Lathyrus sphaericus & 0.057 & 0.437 & Adonis flammea & 0.027 & 0.062 \\
Valerianella coronata & 0.052 & 0.183 & Lamium amplexicaule & 0.024 & 0.056 \\
Sanguisorba minor & 0.050 & 0.229 & Minuartia hybrida & -0.025 & 0.057 \\
Dasypyrum villosum & 0.048 & 0.240 & Cerastium fontanum & -0.026 & 0.051 \\
Eranthis hyemalis & 0.047 & 0.116 & Clematis vitalba & -0.039 & 0.068 \\
Neslia paniculata & 0.046 & 0.155 & Arabidopsis thaliana & -0.041 & 0.143 \\
Alyssum alyssoides & 0.046 & 0.216 & Poa pratensis & -0.046 & 0.070 \\
Carduus pycnocephalus & 0.042 & 0.132 & Capsella bursa-pastoris & -0.060 & 0.070 \\
Vicia tenuifolia & 0.039 & 0.168 & Daucus carota & -0.061 & 0.066 \\
Veronica polita & 0.030 & 0.163 & Aphanes arvensis & -0.061 & 0.076 \\
Polygonum aviculare & -0.106 & 0.132 & Artemisia vulgaris & -0.075 & 0.077 \\
Lolium multiflorum & -0.130 & 0.123 & Veronica persica & -0.077 & 0.103 \\
Anagallis arvensis & -0.130 & 0.230 & Mentha longifolia & -0.107 & 0.128 \\
\hline
\end{tabular}

\begin{tabular}{lcclcc}
\hline $\begin{array}{l}\text { Soil texture } \\
\text { (+ heavy; - loose) }\end{array}$ & Axis 1 score & Fit & $\begin{array}{l}\text { Soil pH }(\mathrm{KCl}) \\
\text { (+ alkaline; - acidic) }\end{array}$ & Axis 1 score & Fit \\
\hline Alopecurus bulbosus & 0.075 & 0.149 & Polygonum aviculare & 0.116 & 0.159 \\
Eranthis hyemalis & 0.051 & 0.140 & Poa annua & 0.100 & 0.109 \\
Centaurea cyanus & 0.050 & 0.094 & Cynodon dactylon & 0.077 & 0.090 \\
Neslia paniculata & 0.050 & 0.182 & Ranunculus sardous & 0.064 & 0.066 \\
Bunium bulbocastanum & 0.047 & 0.147 & Veronica polita & -0.018 & 0.061 \\
Lamium amplexicaule & 0.038 & 0.140 & Cerastium brachypetalum & -0.022 & 0.102 \\
Adonis flammea & 0.038 & 0.124 & Lathyrus sphaericus & -0.023 & 0.069 \\
Lathyrus sphaericus & 0.034 & 0.150 & Adonis flammea & -0.027 & 0.062 \\
Sanguisorba minor & 0.034 & 0.101 & Cruciata pedemontana & -0.029 & 0.078 \\
Cruciata pedemontana & 0.033 & 0.103 & Neslia paniculata & -0.030 & 0.067 \\
Vicia tenuifolia & 0.029 & 0.096 & Dasypyrum villosum & -0.031 & 0.100 \\
Arabidopsis thaliana & -0.034 & 0.099 & Rumex crispus & -0.034 & 0.083 \\
Aphanes arvensis & -0.069 & 0.096 & Centaurea cyanus & -0.044 & 0.072 \\
Chenopodium album & -0.079 & 0.152 & Taraxacum officinale & -0.048 & 0.077 \\
Poa annua & -0.097 & 0.102 & Rubus caesius & -0.063 & 0.093 \\
Bromus madritensis & -0.097 & 0.167 & Galium aparine & -0.071 & 0.069 \\
Capsella bursa-pastoris & -0.106 & 0.221 & Medicago sativa & -0.072 & 0.074 \\
Polygonum aviculare & -0.108 & 0.136 & Vicia sativa & -0.076 \\
Lolium multiflorum & -0.119 & 0.103 & Viola arvensis & 0.064 \\
Matricaria chamomilla & -0.122 & 0.122 & Bromus sterilis & -0.077 & 0.079 \\
\hline
\end{tabular}

\begin{tabular}{lcclrc}
\hline $\begin{array}{l}\text { Soil } \mathrm{CaCO}_{3} \text { content } \\
\text { (+ high; - low) }\end{array}$ & Axis 1 score & Fit & $\begin{array}{l}\text { Soil } \mathrm{P}_{2} \mathrm{O}_{5} \text { content } \\
\text { (+ high; - low) }\end{array}$ & Axis 1 score & Fit \\
\hline Alopecurus myosuroides & 0.110 & 0.080 & Matricaria chamomilla & 0.156 & 0.201 \\
Ranunculus arvensis & 0.077 & 0.069 & Poa annua & 0.133 & 0.191 \\
Veronica hederifolia & 0.058 & 0.036 & Lolium multiflorum & 0.131 & 0.125 \\
Consolida regalis & 0.056 & 0.052 & Capsella bursa-pastoris & 0.111 & 0.240 \\
Symphytum tuberosum & 0.048 & 0.049 & Polygonum aviculare & 0.091 & 0.097 \\
Ranunculus repens & 0.039 & 0.063 & Stellaria media & 0.075 & 0.060 \\
Ranunculus ficaria & 0.038 & 0.088 & Chenopodium album & 0.075 & 0.134
\end{tabular}




\begin{tabular}{|c|c|c|c|c|c|}
\hline Setaria viridis & 0.026 & 0.042 & Papaver hybridum & 0.044 & 0.092 \\
\hline Gladiolus italicus & 0.023 & 0.056 & Arabidopsis thaliana & 0.031 & 0.083 \\
\hline Lamium purpureum & -0.024 & 0.050 & Calendula arvensis & 0.028 & 0.061 \\
\hline Achillea collina & -0.024 & 0.052 & Crepis sancta & 0.022 & 0.069 \\
\hline Trifolium campestre & -0.024 & 0.040 & Euphorbia exigua & -0.021 & 0.052 \\
\hline Medicago polymorpha & -0.024 & 0.075 & Lotus corniculatus & -0.028 & 0.052 \\
\hline Cerastium fontanum & -0.027 & 0.055 & Taraxacum officinale & -0.042 & 0.059 \\
\hline Dasypyrum villosum & -0.027 & 0.077 & Pastinaca sativa & -0.044 & 0.058 \\
\hline Arabidopsis thaliana & -0.033 & 0.091 & Trifolium repens & -0.045 & 0.062 \\
\hline Poa pratensis & -0.034 & 0.037 & Myosotis arvensis & -0.053 & 0.053 \\
\hline Clematis vitalba & -0.038 & 0.063 & Consolida regalis & -0.083 & 0.117 \\
\hline Capsella bursa-pastoris & -0.060 & 0.071 & Anthemis arvensis & -0.093 & 0.067 \\
\hline Lolium multiflorum & -0.101 & 0.074 & Ranunculus arvensis & -0.117 & 0.159 \\
\hline
\end{tabular}




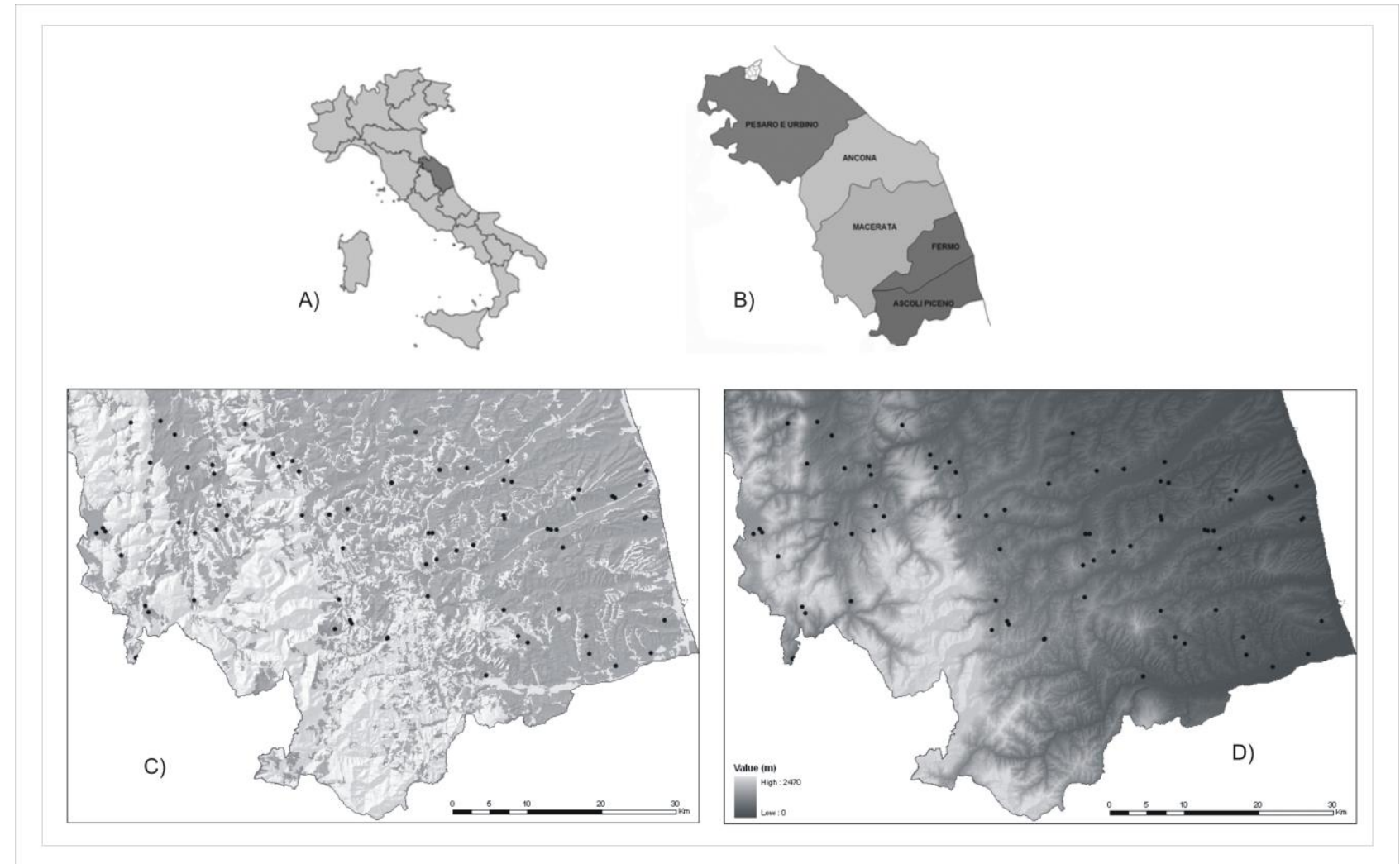

Fig. 1 The location of the study area in the Central Apennines, Italy, southern Marches mountain range, between the provinces of Macerata, Fermo and Ascoli Piceno, outlined in A) and B). Filled dots indicate the position of the 76 sampling areas, illustrated with respect to the distribution of the arable fields C) and with respect to the topography D)
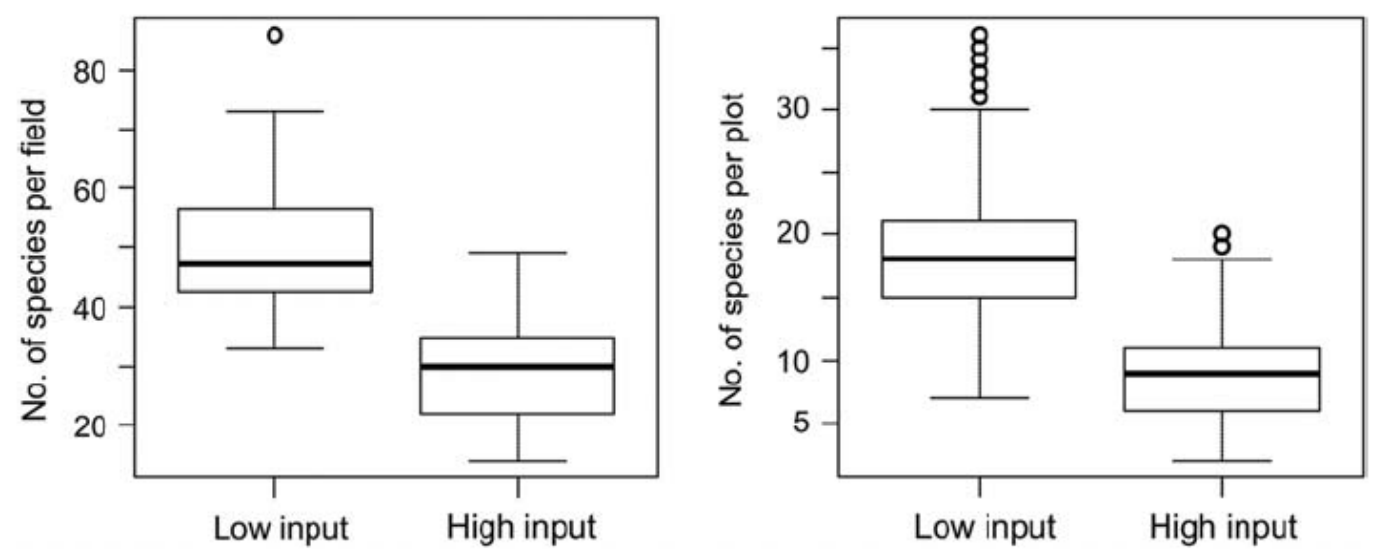

Fig. 2 Differences in the total number of species per field between the two management types: low input $(n=39)$, high input $(n=37)$. The differences are significant at $p<0.001$ (Welch test) 


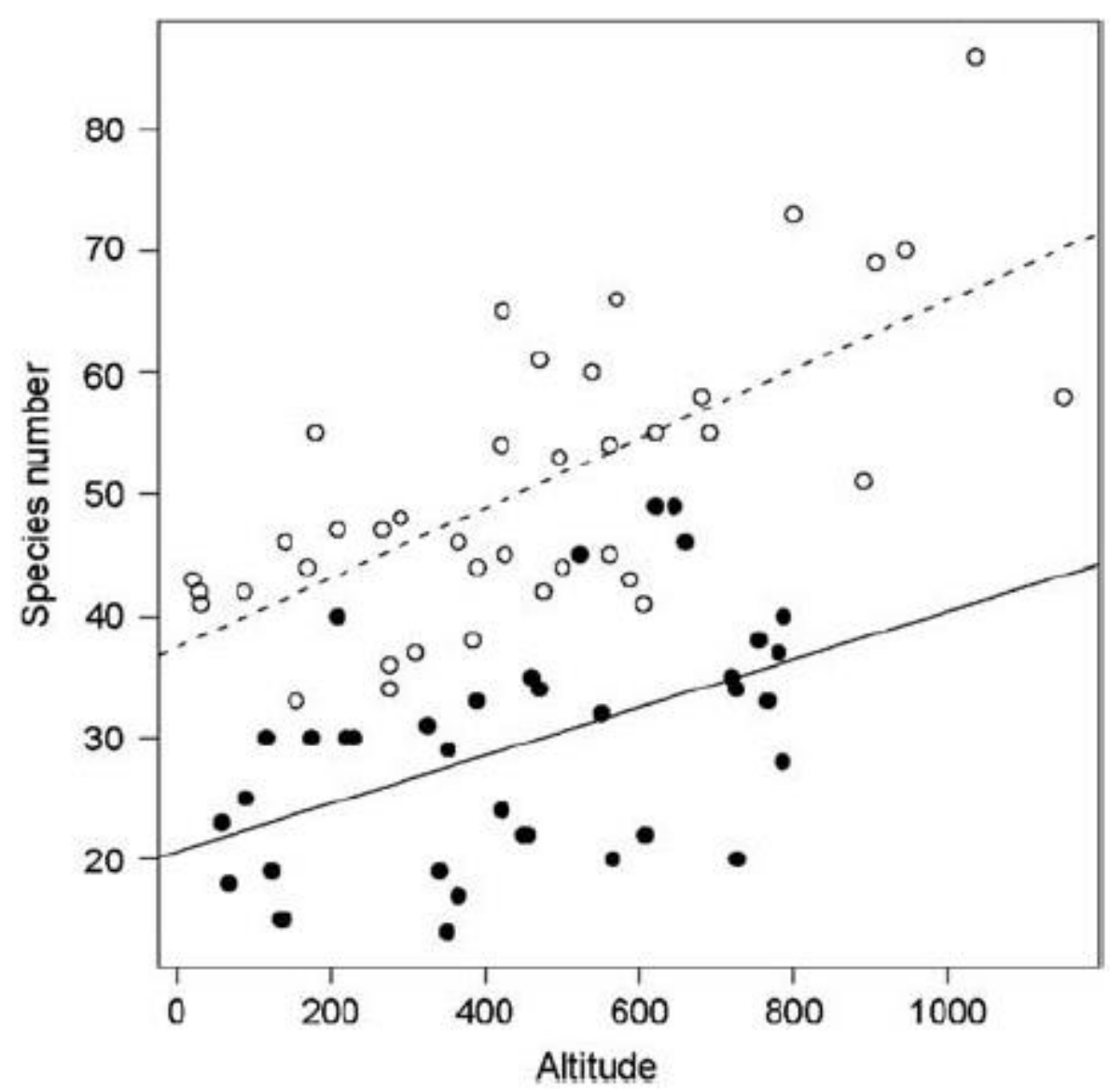

Fig. 3 Species numbers of the plots displayed along the elevation gradient. ○: low input fields, $\bullet$ : intensively-managed fields
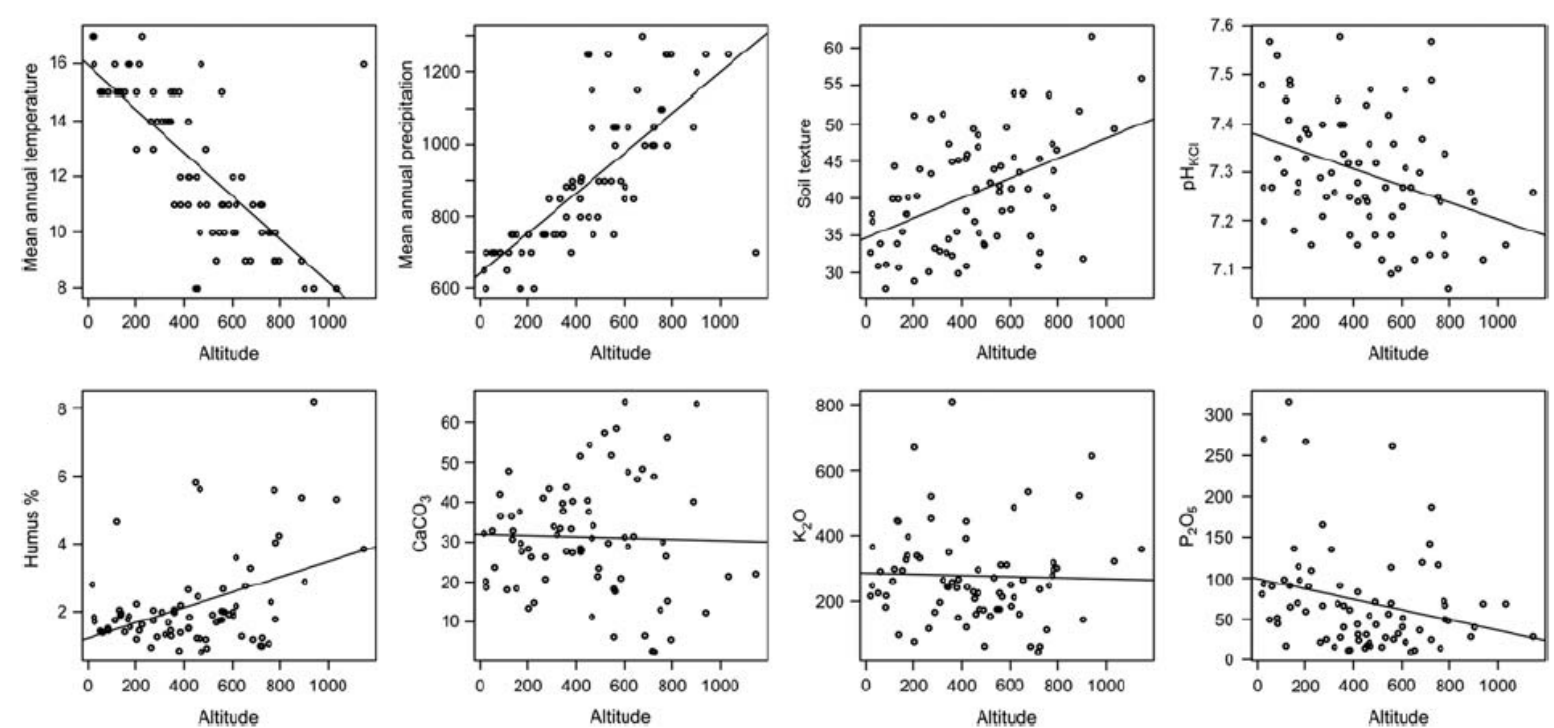

Fig. 4 Correlation between altitude and 8 environmental factors 


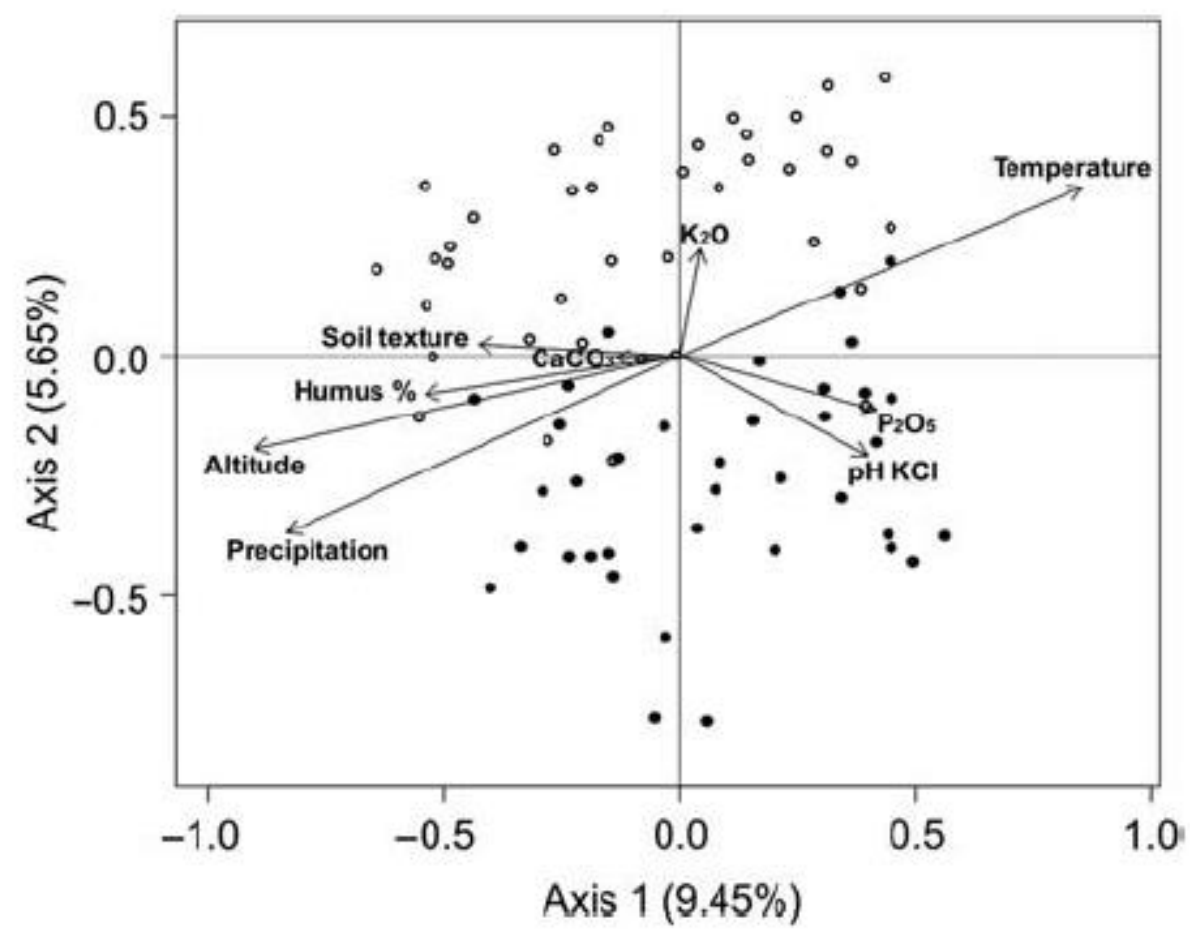

Fig. 5 RDA ordination diagram of environmental variables. $\circ$ : low input fields, •: intensively-managed fields. Eigenvalues of RDA axes are supplied as percentages of the sum of all eigenvalues.

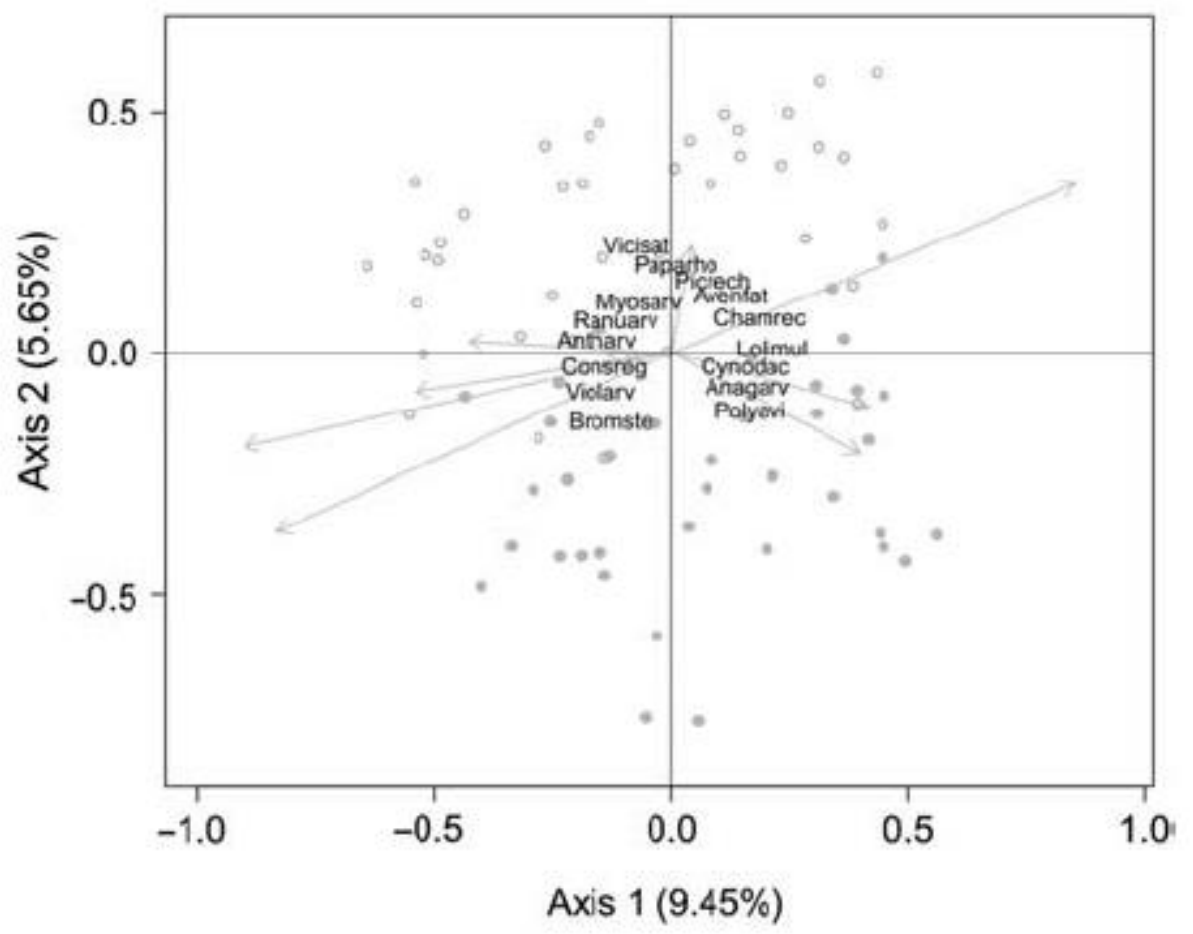

Fig. 6 RDA ordination diagram of the species with the highest fit. $\circ$ : low input fields, •: intensively-managed fields. Species codes: Anagarv = Anagallis arvensis, Anatharv = Anthemis arvensis, Avenfat $=$ Avena fatua, Bromste $=$ Bromus sterilis, Consreg $=$ Consolida regalis, Cynodac $=$ Cynodon dactylon, Picrech $=$ Picris echioides, Lolimul $=$ Lolium multiflorum, Chamrec $=$ Chamomilla recutita, Myosarv $=$ Myosotis arvensis, Paparho $=$ 
Papaver rhoeas, Polyavi $=$ Polygonum aviculare, Ranuarv $=$ Ranunculus arvensis, Vicisat $=$ Vicia sativa, Violarv = Viola arvensis. Eigenvalues of RDA axes are supplied as percentages of the sum of all eigenvalues. 